\section{Depressive symptoms, emotional support and activities of daily living disability onset: 15-year follow-up of the Bambuí (Brazil) Cohort Study of Aging}

\author{
Sintomas depressivos, apoio emocional e início \\ do comprometimento das atividades da vida \\ diária: seguimento de 15 anos do Estudo de \\ Coorte de Idosos de Bambuí, Minas Gerais, Brasil \\ Síntomas depresivos, apoyo emocional y \\ actividades del día a día, conviviendo con la \\ aparición de una discapacidad: seguimiento \\ durante 15 años del Estudio de Cohorte \\ Envejecimiento de Bambuí (Brasil)
}

\author{
Juliana Lustosa Torres 1 \\ Erico Castro-Costa 2 \\ Juliana Vaz de Melo Mambrini 2 \\ Sérgio William Viana Peixoto 2 \\ Breno Satler de Oliveira Diniz 3 \\ Cesar de Oliveira 4 \\ Maria Fernanda Lima-Costa 2
}

doi: 10.1590/0102-311X00141917

\begin{abstract}
Psychosocial factors appear to be associated with increased risk of disability in later life. However, there is a lack of evidence based on long-term longitudinal data from Western low-middle income countries. We investigated whether psychosocial factors at baseline predict new-onset disability in long term in a population-based cohort of older Brazilians adults. We used 15-year followup data from 1,014 participants aged 60 years and older of the Bambui (Brazil) Cohort Study of Aging. Limitations on activities of daily living (ADL) were measured annually, comprising 9,252 measures. Psychosocial factors included depressive symptoms, social support and social network. Potential covariates included sociodemographic characteristics, lifestyle, cognitive function and a physical health score based on 10 self-reported and objectively measured medical conditions. Statistical analysis was based on competitiverisk framework, having death as the competing risk event. Baseline depressive symptoms and emotional support from the closest person were both associated with future $A D L$ disability, independently of potential covariates wide range. The findings showed a clear graded association, in that the risk gradually increased from low emotional support alone (sub-hazard ratio $-S H R=1.11$; 95\%CI: $1.01 ; 1.45)$ to depressive symptoms alone (SHR = 1.52; 95\%CI: 1.13; 2.01) and then to both factors combined (SHR $=1.61 ; 95 \% C I: 1.18 ; 2.18$ ). Marital status and social network size were not associated with incident disability. In a population of older Brazilian adults, lower emotional support and depressive symptoms have independent predictive value for subsequent disability in very long term.
\end{abstract}

Activities of Daily Living; Depression; Social Support; Aged; Cohort Studies

\author{
Correspondence \\ J. L. Torres \\ Universidade Federal de Minas Gerais. \\ Rua Perdigão Malheiros 208, Belo Horizonte, MG 30380-234, \\ Brasil. \\ jlt.fisioufmg@hotmail.com
1 Universidade Federal de Minas Gerais, Belo Horizonte, Brasil. 2 Instituto René Rachou, Fundação Oswaldo Cruz, Belo Horizonte, Brasil.
3 Department of Psychiatry \& Behavioral Sciences, University of Texas Health Science Center at Houston, Houston, U.S.A. 4 Department of Epidemiology es Public Health, University College London, London, U.K.




\section{Introduction}

Disability in later-life is a public health concern worldwide and a new challenge in middle income countries, where the population demographic aging is occurring at an unprecedented pace 1 . Identifying disability predictors of can potentially contribute not only to a better understanding of underlying mechanisms, but also to target vulnerable groups for prevention and early rehabilitation purposes. Psychosocial factors, particularly depression and social resources, appear to be associated with increased risk of physical disability in later life 2,3,4,5. However, the exact role of these characteristics on this association remains uncertain 5.

Depressive symptoms have been reported to be associated with new onset or changes in severity of activity of daily living (ADL) disability in several studies 2,3,4,5. Others, however, have suggested that depression is more likely to be the result of increase in disability rather than a predictor of changes in functional status $6,7,8$. Social resources have also been linked to increased risk, but the kind of resource implicated on the association is debatable. For example, social network and/or social engagement were found to be associated with physical decline in some studies $5,9,10$, while in others social support 4,11,12 and loneliness 13 were associated. Furthermore, a recent report has suggested that the association between social support and physical decline is bidirectional 14. Additionally, social support might be confounded or modified by other factors, like depressive symptoms 15 .

Current evidence on the prognostic value of psychosocial factors and physical decline is based on short (up to 5 years) and medium term (up to 9 years) follow-up data 4,9,10,11,12,13. Therefore, there is a lack of studies examining the association between those factors with incident ADL disability in very long term. Additionally, there is also a shortage of research based on robust long-term longitudinal data on this topic from Western low-middle income countries. Given that those characteristics are likely to be influenced by social, cultural and environmental factors 16 , this gap in the literature is particularly relevant.

Methodological issues must also be considered. For example, in the Bambuí cohort population, death is associated with many age-related outcomes, such as ADL disability, cognitive function, depressive symptoms and cardiovascular risk factors, among others $17,18,19$. Thus, death may represent an informative censoring of the longitudinal outcome that may result in biased estimates of the associations 20 . This increases the challenge of how to account for participants who have died without experiencing disability. Traditional statistical approaches to calculate disease risk, such as the Cox proportional hazard regression, can overestimate the risk of disease by failing to account for the competing risk of death 20,21 . Therefore, using a competing risk approach is critical to accurately assess disability predictors in later life 21 . To our knowledge, no previous study has considered the competing risk of death to examine the association between psychosocial factors and incident ADL disability.

We used 15-year follow-up data from the Bambuí (Brazil) Cohort Study of Aging, the longest community-based cohort study of aging in Brazil 22, to examine the ability of a social support, social network and depressive symptoms baseline measures to predict onset of ADL disability in long term in a Western middle income country.

\section{Methods}

\section{Study design and population}

The Bambuí Cohort Study of Aging was designed to examine the prevalence and incidence of agerelated health outcomes in an older population with low schooling and income levels. Bambuí, where the study was conducted, is a city of approximately 15,000 inhabitants, located in the State of Minas Gerais, in Southeastern Brazil. The cohort procedures have been described in detail elsewhere 22. Briefly, the baseline cohort population comprised all residents aged 60 and over in January 1997 (1,606 from 1,742 older residents participated). Cohort members underwent subsequent annual follow-up by face-to-face interview. Deaths were reported by next of kin during the annual followup (death certificates were obtained for $95 \%$ of all deceased participants). Blood collection and other procedures were performed at baseline and in selected subsequent waves. The Bambuí (Brazil) Cohort 
Study of Aging was approved by the Ethics Research Committee of the Oswaldo Cruz Foundation, Brazil.

\section{Outcome variable}

Annually, from 1997 to 2011, cohort participants were asked about their functioning level, based on the modified version of the Katz Index 23 (difficulty to perform six ADL, namely showering, toileting, dressing, eating, getting in/out of a bed and walking across a room). The questions had four possible answers: no difficulty, some difficulty, great difficulty and unable to perform. New onset disability was considered when a participant reported, for the first time, great difficulty or inability to perform at least one ADL. The year when the new onset occurred was considered the date of onset.

\section{Main predictor variables}

Depressive symptoms were assessed by the 12-item General Health Questionnaire (GHQ-12). Originally, the GHQ was designed for the assessment of common mental disorders 24. In the Bambui cohort population, the GHQ-12 has been shown to have similar accuracy as the 30-item Geriatric Depression Scale (GDS-30) to screen for depressive symptoms in a previous validation study, having as gold standard the diagnosis of major depression ascertained by the Schedules for Clinical Assessment in Neuropsychiatry (SCAN) 25. Its validity for screening depressive disorders has been also recently demonstrated in other populations 26 . A score of $\geq 5$ was recommended for the cohort population to define depressive symptoms 25 . In our initial analysis, we used the quartiles of the GHQ-12 scores distribution to define "major" (scores above the third quartile; i.e. scores $\geq 9$ ), and "minor" depressive symptoms (scores below the third quartile; i.e. scores between 5 and 8), as described elsewhere 17,25.

Psychosocial resources were assessed at baseline and comprised marital status, social support (assessed by positive emotional support) and social network. Marital status was coded as married/ cohabiting, divorced/single and widowed. The Close Persons Questionnaire 27 was used to assess positive aspects of the relationship with the closest person (named by respondents), that encompasses suggestions and guidance, reliance, making the responded to feel good and sharing interests. The fivepoint Likert-scaled response was summed and divided into three groups based on tertile cut-points (< 6, 6-7 and $\geq 8$ represent low, intermediate and high support, respectively). Social network was based on the number of friends or relatives seen monthly (coded as none, 1-2, 3-5 and $\geq 6$ )

\section{Covariates}

The covariates measured at baseline were sociodemographic characteristics (age, gender, schooling years and monthly household income per capita), lifestyle (current smoking and physical activity during previous 3 months), cognitive function (Mini-Mental State Examination - MMSE: applied only to participants that did not need a proxy respondent), and physical health (see below). Because some of the health measures were correlated, we used principal component analysis 28,29 to create a latent variable, i.e. a health score, that included the following conditions: arthritis (any joint diseases), myocardial infarction and stroke (both assessed by a medical diagnosis of the condition), angina pectoris and intermittent claudication 30 , overweight (body mass index $\geq 25 \mathrm{~kg} / \mathrm{m}^{2}$ ), diabetes mellitus (fasting blood glucose $\geq 126 \mathrm{mg} / \mathrm{dL}$ and/or treatment) and heart failure (B-Type Natriuretic Peptic level > $100 \mathrm{pg} / \mathrm{mL}$ ) (all as dichotomous variables), systolic blood pressure and total cholesterol level (both as continuous variables). Scores could range from $-\infty$ to $+\infty$. Higher scores indicated worse health status. The health score was divided into ten groups based on cut-points tentiles.

\section{Statistical analysis}

We used competing-risk regression 31 to estimate the multivariate sub-hazard ratios (SHR) and their $95 \%$ confidence intervals $(95 \% \mathrm{CI})$ to model 15 -year survival-time disability data, after confirming that the assumption of sub-hazards proportionality was met. To consider death that could be related to disability, we used death (i.e., date of death) as a competing risk event. Therefore, our analyses were 
based on the cumulative incidence function, i.e. $C_{k}(t)$, that gives the proportion of subjects at time $t$, who have suffered the event $k$, accounting for the fact that subjects can suffer other events, as follows:

$$
C_{k}(t)=\sum_{t_{j} \leq t} h_{k}\left(t_{j}\right) S\left(t_{j-1}\right)
$$

Where $h_{k}\left(t_{j}\right)$ is the specific risk for the event $k$ at time $t_{j}$, and $S\left(t_{j-1}\right)$ is the probability to survive at time $t_{j-1}$. Similar to Kaplan-Meier's estimations, the general survival probability $S(t)$ is defined as:

$$
S(t)=\pi \underset{t_{j} \leq t}{ }\left(\frac{R\left(t_{j}\right)-d\left(t_{j}\right)}{R\left(t_{j}\right)}\right)
$$

Where $R\left(t_{j}\right)$ is the number of individuals at risk at time $t_{j}$, and $d\left(t_{j}\right)$ is the total number of all events occurred.

The main advantage of using competing risk regression models is that the risk group $R\left(t_{j}\right)$ includes not only those individuals who have not suffer any event, but also those who had suffer the competing event. With this structure, a different hazard function is defined as the probability of the event, given that an individual has survived up to time $t$ without any event, or had had the competing event prior to time $t$. This is the sub-hazard ratio (SHR) 32 .

First, we implemented separate competing-risk regression models for each psychosocial variable (depressive symptoms, marital status, emotional support, and relatives/friends network - all categorized as previously described) to estimate its association with new-onset disability. All models were adjusted for age (continuous), gender, schooling years ( $<4,4-7$ and $\geq 8)$, monthly household income per capita ( $<240.00,241.00-479.00$ and $\geq 480.00$ USD), current smoking (dichotomous), leisure-time physical activities for 20-30 minutes in previous 3 months (never, $<3$ times per week and $\geq 3$ times per week), physical health score (divided into tentile cut-off points) and MMSE score (continuous). Further, we mutually adjusted these psychosocial variables by each other.

Additionally, we used the fully adjusted competitive-risk regression models to examine the separate and combined association of baseline depressive symptoms and emotional support with onset disability. Because "minor" and "major" depressive symptoms showed similar SHR for the outcome, both categories were collapsed, and depressive symptoms were categorized into yes or no (score $\geq 5$ or lower). Similarly, given that only low emotional support showed a statistically significant association with new onset disability, intermediate and high support levels were collapsed, and emotional support was categorized into low and high (score $<6$ or higher). Based on this fully adjusted competitive-risk model, we estimated cumulative incidence rates for disability by year, according to separate and combined depressive symptoms and emotional support categories, and then plotted the results.

Statistical analyses were conducted using Stata 13.0 statistical software (StataCorp LP, College Station, USA).

\section{Results}

Of 1,606 cohort participants, 283 had ADL disability at baseline and were excluded from the current analysis. Thus, the current analysis was based on cohort participants who reported no disability at baseline and who had complete information for all study variables ( 80 were excluded due to use of a proxy respondent and 229 excluded due to missing data), summing 1,014 participants (mean age $=$ 68.6 years). During the study period, 9,252 measures of ADL were collected, 347 participants died, 359 developed ADL disability (incident rate $=38.8$ per 1,000 person-years) and 96 were lost to follow-up. Sociodemographic and other baseline characteristics of study participants are displayed in Table 1.

As shown in Table 2, "minor" and "major" depressive symptoms and low emotional support showed positive statistically significant $(\mathrm{p}<0.05)$ associations with incident disability in the model adjusted for sociodemographic, health characteristics and in the model mutually adjusted for psychosocial factors. Marital status and the size of relatives and friends network did not show statistically significant associations with incident disability in any model. 
Table 1

Characteristics of participants. Bambuí (Brazil) Cohort Study of Aging (1997-2011) (N = 1,014).

\begin{tabular}{|c|c|}
\hline Characteristics & All \\
\hline \multicolumn{2}{|l|}{ Baseline data } \\
\hline Age [mean (SD)] & $68.6(6.7)$ \\
\hline Female gender [\%] & 57.8 \\
\hline Schooling $<4$ years $[\%]$ & 58.2 \\
\hline Monthly household income per capita < USD 480.00 [\%] & 62.7 \\
\hline Current smoker $[\%]$ & 17.3 \\
\hline Leisure-time physical activities more than 3 times a week [\%] & 12.8 \\
\hline MMSE score [median (IQR)] & $22(4)$ \\
\hline Self-reported arthritis [\%] & 23.7 \\
\hline Self-reported myocardial infarction [\%] & 4.8 \\
\hline Self-reported stroke [\%] & 2.5 \\
\hline Angina pectoris (Rose's questionnaire) 30 [\%] & 8.7 \\
\hline Intermittent claudication (Rose's questionnaire) 30 [\%] & 2.7 \\
\hline Overweight $(\mathrm{BMI} \geq 25 \mathrm{~kg} / \mathrm{m} 2)[\%]$ & 48.1 \\
\hline Diabetes mellitus (blood fasting glucose $\geq 126 \mathrm{mg} / \mathrm{dL}$ and/or treatment [\%] & 14.5 \\
\hline Heart failure (B-Type Natriuretic Peptic level > 100pg/mL) [median (IQR)] & 38.6 \\
\hline Systolic blood pressure in mmHg [mean (SD)] & $137(21.7)$ \\
\hline Total cholesterol in mg/dL [mean (SD)] & $235(49.0)$ \\
\hline Physical health score [median (IQR)] & $0.06(-0.85,0.92)$ \\
\hline \multicolumn{2}{|l|}{ Follow-up data } \\
\hline Interviews [n] & 9,252 \\
\hline Deaths $[\mathrm{n}(\%)]$ & $347(34.2)$ \\
\hline Loss to follow-up $[n(\%)]$ & $96(9.5)$ \\
\hline New-onset of ADL disability [n (rate per 1,000 person-years)] & $359(38.8)$ \\
\hline
\end{tabular}

ADL: activities of daily living; BMI: body masss index; IQR: interquartile range; MMSE: Mini-Mental State Examination; SD: standard deviation.

Table 3 shows the results of the separate and combined association multivariate analysis of depressive symptoms and emotional support with onset of ADL disability. Regarding those with no depressive symptoms and high support, low emotional support and depressive symptoms alone increased the risk of disability $(\mathrm{SHR}=1.11 ; 95 \% \mathrm{CI}: 1.01 ; 1.45$ and SHR $=1.52 ; 95 \% \mathrm{CI}: 1.13 ; 2.01$, respectively). The presence of both factors increased the risk of disability by 1.61 (95\%CI: $1.18 ; 2.18)$. No statistically significant interaction ( $\mathrm{p}>0.05$ ) between those two factors on the disability risk was found.

Figure 1 shows the disability cumulative probability by year, according to separate and combined baseline depressive symptoms and emotional support. The clearly separated lines highlights the graded association between those factors and the risk of disability showed in Table 3 .

\section{Discussion}

The key findings from our analysis are that baseline measures of both depressive symptoms and emotional support (as assessed by emotional relationship with the closest person), have predictive value for incident disability in long term, independently of an array of potential confounding variables. Moreover, when combined, the association between those factors and incident ADL disability showed a clear graded association, in that risk increases gradually from low emotional support alone to depressive symptoms alone and then to both factors together. Marital status and the size of social network were not associated with incident disability. The absence of these associations agrees with previous research, suggesting that it is the quality, not the size of the network, which counts for the prediction of disability in late life $4,11,13$. 
Table 2

Baseline psychosocial measures and their association with 15-year onset of activities of daily living (ADL) disability. Bambuí (Brazil) Cohort Study of Aging (1997-2011)

\begin{tabular}{|c|c|c|c|c|}
\hline Measures & $\begin{array}{l}\text { Prevalence at } \\
\text { the baseline } \\
(\mathrm{N}=1,014)\end{array}$ & $\begin{array}{c}\text { Number of } \\
\text { onsets } \\
\text { (incident rate } \\
\text { per } 1,000 \\
\text { person-years) }\end{array}$ & $\begin{array}{l}\text { SHR }(95 \% \mathrm{Cl}) \text { adjusted } \\
\text { for sociodemographic } \\
\text { and health variables * }\end{array}$ & $\begin{array}{l}\text { SHR }(95 \% \mathrm{Cl}) \text { adjusted } \\
\text { for sociodemographic } \\
\text { and health variables } \\
\text { and mutually adjusted } \\
\text { for psychosocial factors } \\
\text { listed in the table }\end{array}$ \\
\hline \multicolumn{5}{|c|}{ Depressive symptoms (GHQ-12 cut-off points) } \\
\hline No $(<5)$ & 66.6 & $208(31.8)$ & 1.00 & 1.00 \\
\hline Minor (5-8) & 23.1 & $104(54.6)$ & $1.45(1.14 ; 1.83)$ & $1.41(1.11 ; 1.79)$ \\
\hline Major ( $\geq 9)$ & 10.4 & $47(57.9)$ & $1.49(1.08 ; 2.04)$ & $1.43(1.03 ; 1.98)$ \\
\hline \multicolumn{5}{|l|}{ Marital status } \\
\hline Married/Cohabiting & 52.6 & $167(32.5)$ & 1.00 & 1.00 \\
\hline Divorced/Single & 14.6 & $51(40.0)$ & $0.94(0.68 ; 1.29)$ & $0.89(0.64 ; 1.23)$ \\
\hline Widowed & 32.8 & $141(50.0)$ & $0.97(0.75 ; 1.25)$ & $0.96(0.74 ; 1.24)$ \\
\hline \multicolumn{5}{|c|}{ Emotional support in tertiles (cut-off points) } \\
\hline $\operatorname{High}(\geq 8)$ & 32.5 & $97(31.3)$ & 1.00 & 1.00 \\
\hline Intermediate (6-7) & 27.0 & $106(42.2)$ & $1.34(1.02 ; 1.75)$ & $1.26(0.95 ; 1.67)$ \\
\hline $\operatorname{Low}(<6)$ & 40.5 & $156(42.8)$ & $1.34(1.04 ; 1.73)$ & $1.31(1.01 ; 1.69)$ \\
\hline \multicolumn{5}{|c|}{$\begin{array}{l}\text { Number of relatives seen once a month or } \\
\text { more }\end{array}$} \\
\hline None & 15.7 & $60(46.1)$ & 1.00 & 1.00 \\
\hline $1-2$ & 15.9 & $51(34.4)$ & $0.79(0.55 ; 1.14)$ & $0.82(0.57 ; 1.19)$ \\
\hline $3-5$ & 32.9 & $122(40.0)$ & $0.90(0.67 ; 1.21)$ & $0.96(0.71 ; 1.30)$ \\
\hline$\geq 6$ & 35.5 & $121(37.1)$ & $0.97(0.72 ; 1.29)$ & $1.06(0.78 ; 1.45)$ \\
\hline \multicolumn{5}{|c|}{ Number of friends seen once a month or more } \\
\hline None & 5.4 & $23(32.8)$ & 1.00 & 1.00 \\
\hline $1-2$ & 11.1 & $51(47.0)$ & $1.04(0.65 ; 1.67)$ & $1.04(0.64 ; 1.69)$ \\
\hline $3-5$ & 32.4 & $110(40.0)$ & $0.83(0.54 ; 1.30)$ & $0.82(0.53 ; 1.29)$ \\
\hline$\geq 6$ & 51.2 & $175(33.7)$ & $0.83(0.54 ; 1.28)$ & $0.81(0.57 ; 1.19)$ \\
\hline
\end{tabular}

95\%Cl: 95\% confidence interval; GHQ-12: 12-item General Health Questionnaire; SHR: sub-hazard ratios.

Note: SHR $(95 \% \mathrm{Cl})$ estimated by competing-risk regression.

* Adjusted for age (continuous), gender, schooling years ( $<4,4-7$ and $\geq 8$ ) and monthly household income per capita $(<240.00,241.00-479.00$

and $\geq 480.00$ USD), current smoking (dichotomous), leisure-time physical activities for 20-30 minutes in previous 3 months (never, $<3$ times per week and $\geq 3$ times per week), physical health score (based on medical conditions shown in Table 1 and divided into tentile cut-off points) and Mini-Mental State Examination (MMSE) score (continuous).

Depression has been postulated as an important underlying mechanism for physical decline in late-life, but the direction of the association between depressive symptoms and disability is controversial 2,3,4,5,6,7,8. For example, results from three recent large longitudinal studies reported that: (1) baseline severe depression is an independent predictor of incident ADL among women, but not men 3; (2) depressive symptoms and disability are longitudinally associated 4,8 , in the sense that depressive symptoms slightly increase with approaching disability, increase at onset, and decline in the post disability phase 4; (3) depressive symptoms are associated with new-onset ADL disability but not with progression of disability 5 ; (4) the association between depressive symptoms with disability appears to be bidirectional 6,7 . In the current analysis, a single baseline depressive symptoms measure showed predictive value for future ADL disability in long term.

There is a vast literature, as indicated by a comprehensive meta-analysis 33 , that social support is a robust predictor of future morbidity and mortality. However, there is a concern that social support 
Table 3

Separate and combined association of baseline depressive symptoms and emotional support level with 15-year onset of activities of daily living (ADL) disability. Bambuí (Brazil) Cohort Study of Aging (1997-2011).

\begin{tabular}{lccc}
\hline Variables * & $\begin{array}{c}\text { Prevalence at the } \\
\text { baseline } \\
(\mathbf{N}=\mathbf{1 , 0 1 4 )}\end{array}$ & $\begin{array}{c}\text { Number of onsets } \\
\text { (incident rate per 1,000 person- } \\
\text { years) }\end{array}$ & $\begin{array}{c}\text { SHR (95\%Cl) adjusted for } \\
\text { sociodemographic, health and } \\
\text { psychosocial factors ** }\end{array}$ \\
\hline $\begin{array}{l}\text { No depressive symptoms and high } \\
\text { support }\end{array}$ & 41.0 & $119(29.2)$ & 1.00 \\
No depressive symptoms and low & 25.5 & $89(36.1)$ & $1.11(1.01 ; 1.45) * * *$ \\
support & 18.4 & $18.4(54.6)$ & $1.52(1.13 ; 2.01) * * *$ \\
$\begin{array}{l}\text { Depressive symptoms and high } \\
\text { support } \\
\text { Depressive symptoms and low } \\
\text { support }\end{array}$ & 15.0 & $67(57.0)$ & $1.61(1.18 ; 2.18) * * *$ \\
\hline
\end{tabular}

95\%Cl: 95\% confidence interval; GHQ-12: 12-item General Health Questionnaire; SHR: sub-hazard ratios.

Note: SHR $(95 \% \mathrm{Cl})$ estimated by competing-risk regression.

* Depressive symptoms were categorized into GHQ-12 score $\geq 5$ or less. Low support was defined as score $<6$;

** Adjusted for age (continuous), gender, schooling years ( $<4,4-7$ and $\geq 8)$ and monthly household income per capita $(<240.00,241.00-479.00$ and $\geq 480.00$ USD), current smoking (dichotomous), leisure-time physical activities for 20-30 minutes in previous 3 months (never, $<3$ times per week and $\geq 3$ times per week), physical health score (based on medical conditions shown in Table 1 and divided into tentile cut-off points), Mini-Mental State Examination (MMSE) score (continuous), marital status, and number of relatives and number of friends seen once a month, as specified in Table 2; $* \star * p<0.05$.

\section{Figure 1}

Fully adjusted incidence rates * of 15-year onset of activities of daily living (ADL) disability, according to baseline separated and combined depressive symptoms and emotional support level. Bambuí (Brazil) Cohort Study of Aging (1997-2011).

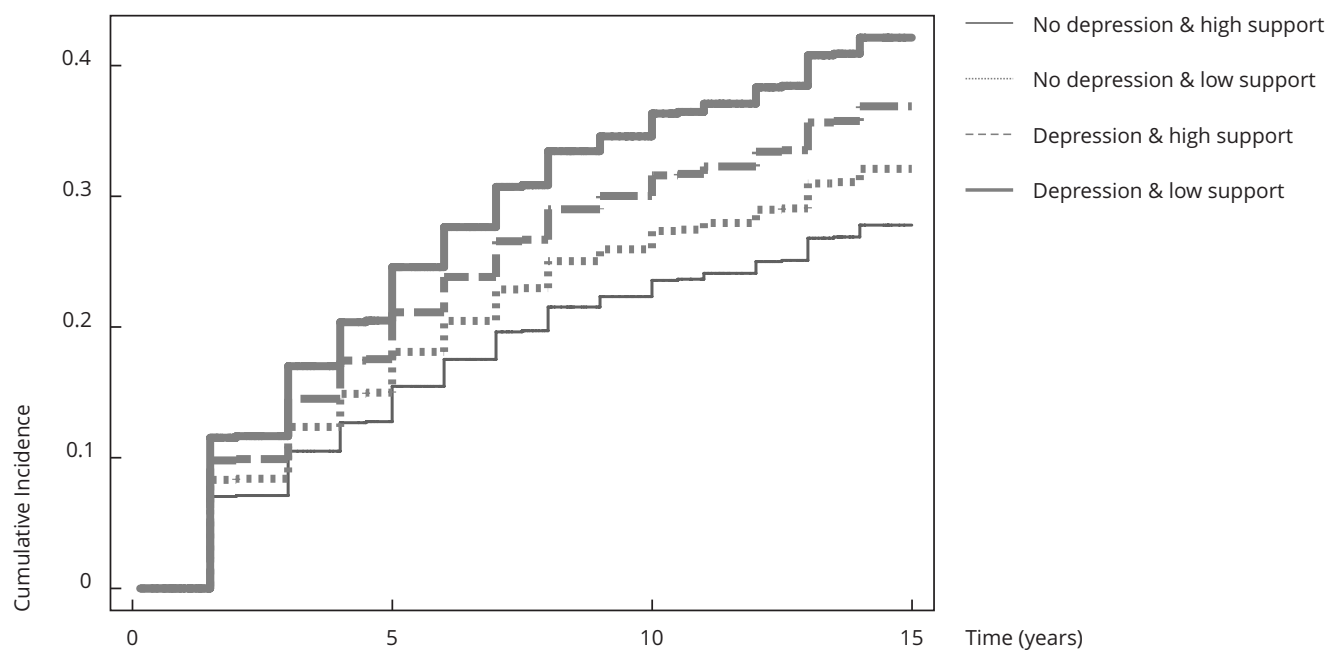

* Incidence rates were estimated by competing-risk regression and adjusted for sociodemographic variables, lifestyle and physical health score, as specified in Table 2. Number of participants is equal to 1,014. 
might be confounded with other factors, especially those related to mental health 15 . This is because psychological mechanisms, such as depression and perceived stress, are the mostly common postulated pathways linking social support to health. An additional concern is that depression might bias perception of support 15. Low emotional support, in our analysis, was associated with the onset of disability after controlling for depressive symptoms, other psychosocial factors and a wide range of relevant conditions.

To our knowledge, no previous study has specifically examined the predictive value of low positive emotional support from the closest person for disability. Negative emotional support from the closest person has been reported to predict several conditions that may predispose to physical disability and cognitive functioning decline 34 , sleep problems 35 , maintenance of recommended levels of physical activity 36 and coronary events ${ }^{37}$. Despite controlling for lifestyle variables and important health indicators, we do not know how these measures have changed in the subsequent wave. Thus, the effect of longitudinal changes of those variables on the association between depressive symptoms, social support and physical decline is a matter of further research.

Strengths of this study include its well-defined community-dwelling sample of older adults followed for an extended period, annual measures of functioning, and minimal follow-up loss. A limitation in our study is inherent to all longitudinal studies of aging. Older adults are at increased risk of death, which, in turn, might lead to differential censoring, that is, people who died are more or less likely to undergo the event of interest than those who have survived 20. As an attempt to overcome this potential source of bias, we used a competing risk framework in our analysis 31 . Another limitation is the use of a single baseline measure of depressive symptoms and emotional support, which reflect recent perceptions. However, we emphasize that those single measures, independently of a wide range of health conditions that could confound the association, were associated with new-onset disability in a very long term.

In conclusion, there has been a recent interest in the usefulness of identifying psychosocial factors to screen people at increased risk of disability for the prevention and early rehabilitation purposes 13 . Our results show that depressive symptoms and lower emotional support from the closest person have strong predictive value for subsequent ADL disability in a cohort of Brazilian older adults with low schooling and income levels, independently of a relevant covariates array. This suggests that older adults reporting depressive symptoms and lower emotional support deserve further attention in clinical setting, especially when both conditions are present.

\section{Contributors}

J. L. Torres and M. F. Lima-Costa participated in the conceptualization, data curation, formal analysis, investigation, methodology, project administration, resources, software, validation and writing of the article. E. Castro-Costa and B. S. O. Diniz contributed in the data curation, formal analysis and writing of the article. J. V. M. Mambrini participated in the data curation, formal analysis, software andwriting of the article. S. W. V. Peixoto contributed in the software, formal analysis writing of the article. C. Oliveira participated in the formal analysis, investigation, project administration, software, validation writing of the article.

\section{Acknowledgments}

We want to thank our Brazilian study supporters, the Brazilian National Research Council (CNPq), the Graduate Studies Coordinating Board (Capes), Brazilian Ministry of Education, and the Minas Gerais State Research Foundation (FAPEMIG). M. F. Lima-Costa and S. W. V. Peixoto are fellow researchers of the CNPq. J. L. Torres is fellow research of Capes. 


\section{References}

1. National Institute on Aging, National Institute of Health, U.S. National Institute of Aging; World Health Organization. Global health and aging. Washington DC: National Institute of Health; 2011. (NIH Publication, 11-7737).

2. Alexandre TS, Corona LP, Nunes DP, Santos JL, Duarte YA, Lebrão ML. Gender differences in incidence and determinants of disability in activities of daily living among elderly individuals: SABE study. Arch Gerontol Geriatr 2012; 55:431-7.

3. Carrière I, Gutierrez LA, Pérès K, Berr C, Barberger-Gateau P, Ritchie K, et al. Late life depression and incident activity limitations: influence of gender and symptom severity. J Affect Disord 2011; 133:42-50.

4. Fauth EB, Gerstorf D, Ram N, Malmberg B. Changes in depressive symptoms in the context of disablement processes: role of demographic characteristics, cognitive function, health, and social support. J Gerontol B Psychol Sci Soc Sci 2012; 67:167-77.

5. Mendes de Leon CF, Rajan KB. Psychosocial influences in onset and progression of late life disability. J Gerontol B Pshycol Sci Soc Sci 2014; 69:287-302.

6. Chen C, Mullan J, Su Y, Kreis I. The longitudinal relationship between depression symptoms and disability for older adults: a population-based study. J Gerontol A Biol Sci Med Sci 2012; 67:1059-67.

7. Chao SF. Functional disability and depressive symptoms: longitudinal effects of activity restriction, perceived stress, and social support. Aging Ment Health 2014; 18:767-76.

8. Yang Y, George LK. Functional disability, disability transitions, and depressive symptoms in late life. J Aging Health 2005; 17:263-92.

9. James BD, Boyle PA, Buchman AS, Bennett DA. Relation of late-life social activity with incident disability among community-dwelling older adults. J Gerontol A Biol Sci Med Sci 2011; 66:467-73.

10. Lund R, Nilsson CJ, Avlund K. Can the higher risk of disability onset among older people who live alone be alleviated by strong social relations? A longitudinal study of non-disabled men and women. Age Ageing 2010; 39:319-26.
11. Chen C, Chang W, Lan T. Identifying factors associated with changes in physical functioning in an older population. Geriatr Gerontol Int 2015; 15:156-64.

12. McLaughlin D, Leung J, Pachana N, Flicker L, Hankey G, Dobson A. Social support and subsequent disability: it is not the size of your network that counts. Age Ageing 2012; 41:674-7.

13. Perissionotto CM, Cenzer IS, Covinsky KE. Loneliness in older persons. Arch Intern Med 2012; 172:1078-83.

14. Hakulinen C, Pulkki-Råback L, Jokela M, Ferrie JE, Aalto AM, Virtanen M, et al. Structural and functional aspects of social support as predictors of mental and physical health trajectories: Whitehall II cohort study. J Epidemiol Community Health 2016; 70:710-5.

15. Uchino BN, Bowen K, Carlisle M, Birmingham W. Psychological pathways linking social support to health outcomes: a visit with the "ghosts" of research past, present, and future. Soc Sci Med 2012; 74:949-57.

16. Field MJ, Jette AM. The future of disability in America. Washington DC: National Academies Press; 2007.

17. Diniz BS, Reynolds 3rd CF, Butters MA, Dew MA, Firmo JO, Lima-Costa MF, et al. The effect of gender, age, and symptom severity in late-life depression on the risk of all-cause mortality: the Bambuí Cohort Study of Aging. Depress Anxiety 2014; 31:787-95.

18. Lima-Costa MF, Cesar CC, Peixoto SV, Ribeiro AL. Plasma B-type natriuretic peptide as a predictor of mortality in community-dwelling older adults with Chagas disease: 10-year follow-up of the Bambuí Cohort Study of Aging. Am J Epidemiol 2010; 172:190-6.

19. Lima-Costa MF, Peixoto SV, Matos DL, Firmo JOA, Uchôa E. Predictors of 10-year mortality in a population of community-dwelling Brazilian elderly: the Bambuí Cohort Study of Aging. Cad Saúde Pública 2011; 27 Suppl 3:S360-9. 
20. Murphy TE, Han L, Allore HG, Peduzzi PN, Gill TM, Lin H. Treatment of death in the analysis of longitudinal studies of gerontological outcomes. J Gerontol A Biol Sci Med Sci 2011; 66:109-14.

21. Barry SD, Ngo L, Samelson EJ, Kieal DP. Competing risk of death: an important consideration in studies of older adults. J Am Geriatr Soc 2010; 58:783-7.

22. Lima-Costa MF, Firmo JO, Uchôa E. Cohort profile: the Bambuí (Brazil) Cohort Study of Aging. Int J Epidemiol 2011; 40:862-7.

23. Katz S, Akpom CA. A measure of primary sociobiological functions. Int J Health Serv 1976; 6:493-508.

24. Goldberg DP, Blackwell B. Psychiatric illness in general practice: a detailed study using a new method of case identification. Br Med J 1970; 2:439-43.

25. Castro-Costa E, Barreto SM, Uchôa E, Firmo JO, Lima-Costa MF, Prince M. Is the GDS-30 better than the GHQ-12 for screening depression in the elderly people in the community? The Bambuí Health Aging Study (BHAS). Int Psychogeriatr 2006; 18:493-503.

26. Lundin A, Hallgren M, Theobald H, Hellgren C, Torgén M. Validity of the 12 -item version of General Health Questionnaire in detecting depression in the general population. Public Health 2016; 136:66-74.

27. Stansfeld S, Marmot M. Deriving a survey measure of social support: the reliability and validity of the Close Persons Questionnaire. Soc Sci Med 1992; 35:1027-35.
28. Ismail K. Unravelling factor analysis. Evid Based Ment Health 2008; 11:99-102.

29. Vyas S, Kumaranayake L. Constructing socioeconomic status indices: how to use principal components analysis. Am J Epidemiol 2012; 175:228-35.

30. Rose GA. The diagnosis of ischaemic heart pain and intermittent claudication in field surveys. Bull World Health Organ 1962; 27:64558.

31. Fine JP, Gray RJ. A proportional hazards model for the subdistribution of a competing risk. J Am Stat Assoc 1999; 94:496-509.

32. Lau B, Cole SR, Gange SJ. Competing risk regression models for epidemiologic data. Am J Epidemiol 2009; 170:244-56.

33. Holt-Lunstad J, Smith TB, Layton JB. Social relationships and mortality risk: a meta-analytic review. PLoS Med 2010; 7:e1000316.

34. Liao J, Head J, Kumari M, Stansfeld S, Kivimaki M, Singh-Manoux A, et al. Negative aspects of close relationships as risk factors for cognitive aging. Am J Epidemiol 2014; 180:1118-25.

35. Steptoe A, O’Donnell K, Marmot M, Wardle J. Positive affect, psychological well-being, and good sleep. J Psychosom Res 2008; 64:409-15.

36. Watt RG, Heilmann A, Sabbah W, Newton T, Chandola T, Aida J, et al. Social relationships and health related behaviors among older US adults. BMC Public Health 2014; 14:533.

37. De Vogli R, Chandola T, Marmot MG. Negative aspects of close relationships and heart disease. Arch Intern Med 2007; 167:1951-7. 


\section{Resumo}

Fatores psicossociais parecem estar associados a um aumento do risco de incapacidade em idosos. Entretanto, faltam evidências baseadas em dados longitudinais de longo prazo em países ocidentais de renda baixa e média. Investigamos se os fatores psicossociais presentes na linha de base predizem a incapacidade incidente no longo prazo em uma coorte populacional de idosos brasileiros. Usamos dados do seguimento de 15 anos de 1.014 participantes com 60 anos de idade ou mais do Estudo de Coorte de Idosos de Bambuí, Minas Gerais, Brasil. Foram medidas anualmente as limitações nas atividades de vida diária (AVD), totalizando 9.252 mensurações. Os fatores psicossociais incluíram sintomas depressivos, apoio emocional e rede social. As variáveis independentes incluíram características sociodemográficas, estilo de vida, função cognitiva e uma escala de saúde física com dez condições clínicas autorrelatadas e medidas objetivas. A análise estatística foi baseada em um modelo de risco competitivo, tendo o óbito como evento de risco competitivo. Os sintomas depressivos na linha de base e o apoio emocional da pessoa mais próxima estiveram associados à incapacidade futura nas AVD, independentemente da grande amplitude das variáveis independentes. Os achados mostraram um claro gradiente de associação, onde o risco aumentou progressivamente desde o baixo apoio emocional isoladamente (sub-hazard ratio $-S H R=1,11 ;$ IC95\%: 1,$01 ; 1,45)$ para sintomas depressivos isoladamente $(S H R=1,52$; IC95\%: 1,13 ; 2,01) até a combinação de ambos os fatores (SHR = 1,61; IC95\%: 1,18; 2,18). O estado civil e o tamanho da rede social não mostraram associação com a mortalidade incidente. Em uma população de idosos brasileiros, o apoio emocional baixo e sintomas depressivos apresentam valores preditivos independentes em relação à incapacidade subsequente no prazo muito longo.

Atividades Cotidianas; Depressão; Apoio Social; Idoso; Estudos de Coortes

\section{Resumen}

Los factores psicosociales parecen que estaban asociados con un aumento del riesgo de sufrir discapacidad más adelante a lo largo de la vida. Sin embargo, existe una falta de evidencias en los datos a largo plazo de carácter longitudinal, procedentes de países occidentales con una renta medio-baja. Investigamos si los factores psicosociales como base de referencia predicen un surgimiento de discapacidad a largo plazo en una cohorte de población, basada en adultos ancianos brasileños. Se realizó un seguimiento durante 15 años con datos de 1.014 participantes con 60 años y de mayor edad en el Estudio de Cohorte Envejecimiento de Bambui (Brasil). Las limitaciones en las actividades de la vida diaria (ADL por sus siglas en inglés) fueron medidas anualmente, comprendiendo 9.252 medidas. Se trabajó con factores psicosociales, incluidos síntomas depresivos, apoyo social y tejido social. Las covariables potenciales incluyeron características sociodemográficas, estilo de vida, función cognitiva y un marcador de salud física, basado en 10 condiciones médicas autoinformadas y medidas objetivamente. El análisis estadístico estaba basado en un marco de riesgo competitivo, considerando la muerte como riesgo competitivo. Las bases de referencia de los sintomas depresivos y el apoyo emocional de la persona más cercana estuvieron asociadas con una futura discapacidad $A D L$, independientemente del extenso rango de potenciales covariables. Los resultados muestran un clara asociación graduada, en la que el riesgo gradualmente aumentó desde un bajo apoyo emocional solo (sub-hazard ratio $-S H R=1,11$; IC95\%: 1,$01 ; 1,45)$ para sintomas depresivos sólo $(S H R=1.52$; IC95\%: 1,13; 2,01) y luego para ambos factores combinados (SHR = 1,61; IC95\%: 1.18; 2.18). El estado marital y el tamaño del tejido social no estuvieron asociados con la incidencia de discapacidad. En una población de adultos mayores brasileños, un apoyo emocional más bajo y sintomas depresivos poseen un valor predictivo independiente para una consecuente discapacidad a muy largo plazo.

Atividades Cotidianas; Depresión; Apoyo Social; Anciano; Estudios de Cohortes

Submitted on 18/Aug/2017

Final version resubmitted on 21/Dec/2017

Approved on 26/Jan/2018 